\title{
The Impact of Willow Flowering Time on Species Composition and the Number of Apoidea Pollinators
}

\author{
Monika Konatowska' ${ }^{1}$, Paweł Rutkowski' ${ }^{1}$, Jacek Wendzonka ${ }^{2}$ \\ ${ }^{1}$ Poznań University of Life Sciences, Poznan, Poland \\ ${ }^{2}$ Adam Mickiewicz University, Poznan, Poland \\ Email: monika.konatowska@up.poznan.pl, pawel.rutkowski@up.poznan.pl, setauron@gmail.com
}

How to cite this paper: Konatowska, M., Rutkowski, P. and Wendzonka, J. (2021) The Impact of Willow Flowering Time on Species Composition and the Number of Apoidea Pollinators. Journal of Biosciences and Medicines, 9, 89-100.

https://doi.org/10.4236/jbm.2021.911009

Received: October 28, 2021

Accepted: November 27, 2021

Published: November 30, 2021

\begin{abstract}
Pollinators are important to wild and cultivated plants, and the same plants are important to pollinators as well. A very important source of pollen and nectar to pollinators are willows (Salix spp.). The aim of this study was to demonstrate which Apoidea species are attracted by a species-diverse willow plantation (Poznan University of Life Sciences Willow Collection, Poland), the proportion of the number of honeybees to other species from the Apoidea superfamily visiting willow plantations, and whether the flowering date of male and female willow individuals affect the species composition and number of pollinators. Observations of willow phenology were carried out in the second year of willow growth, from March 9 to December 7, 2012. The insects were observed between April 6 and May 11, 2012. The results of this study showed 30 Apoidea species. Among 1591 Apoidea individuals, only 17 honeybee individuals were noted. The results show that the willow pollen production optimum occurred when the minimum air temperatures stopped dropping below zero. This parameter and this period are also related to the intensification of the occurrence of the noted insects. It can also be concluded that the pollen production season precedes the flowering optimum of female flowers and that the optimum flowering of female flowers is correlated with a significant increase in air temperature.
\end{abstract}

\section{Keywords}

Willows, Apoidea Pollinators, Air Temperature

\section{Introduction}

Pollinators are important to wild and cultivated plants, but the same plants are 
important to pollinators. A very important source of pollen and nectar for supporting pollinator populations early in the growing season are willows (Salix spp.) [1]. In the Polish flora there are 26 native species of Salix genera, but many non-native willows were introduced to Poland because of their utility as a source of renewable energy, in basketry, medicine, and furniture industries, phytoremediation and many other fields. The results of Konatowska et al. [2], conducted on 150 genotypes of willows, including 8 species, 16 interspecies hybrids, cultivars, and sex-differentiated specimens from Poznań University of Life Sciences Willow Collection indicated that in all papers devoted to willows, both practical and scientific, it is necessary to refer not only to the willow species and environmental conditions in which they grow, but also to the sex of the examined or cultivated individuals. It is especially important for pollinators. In many studies, the alarm sounds that pollinators are threatened, but most articles refer to honeybees. However, wild native bee populations have also been declining due to the loss and degradation of nesting sites and floral resources [1]. Therefore, the aim of this study was to demonstrate which Apoidea species are attracted by a species-diverse willow plantation, the proportion of the number of honeybees to other species from the Apoidea superfamily visiting willow plantations, and whether the flowering date of male and female willow individuals affects the species composition and the number of pollinators.

Plants of Salix genera produce catkins reminiscent of anemophilous inflorescences but also possess traits typical of entomophilous flowers such as nectaries and sculpted pollen. Thus, the pollination mode of willows has been considered to be transitional between entomophily and anemophily [3]. However, the citied authors have shown that $99.9 \%$ of seeds of tested Salix lasiolepis resulted from insect visitation while $0.1 \%$ resulted from wind transferred pollen and concluded that insects are the chief pollen vectors. However, other authors note that the role of insects and wind could depend on willow species and ecological context [3]-[9].

These divergent views may be one of the reasons why Füssel [10] found that despite the worldwide distribution and great ecological importance of willows, little is known about the specific interaction of Salix species with their pollinators. The most important managed pollinators are honeybees and bumblebees [11], but the interactions between honeybees and the wild species are not much studied [12]. Therefore relationships between willows, honeybees and other pollinators seem to be an important objective of the studies.

\section{Research Area and Methods}

\subsection{Research Area}

Nicholson \& Wright [13] stated, that for pollinators, the maintenance of connectivity and landscape heterogeneity is critical. The research area represents a high level of heterogeneity, including: forests, arable lands, and waters with at radius of $300 \mathrm{~m}$ from the center of research area (Figure 1). Under such conditions, in 

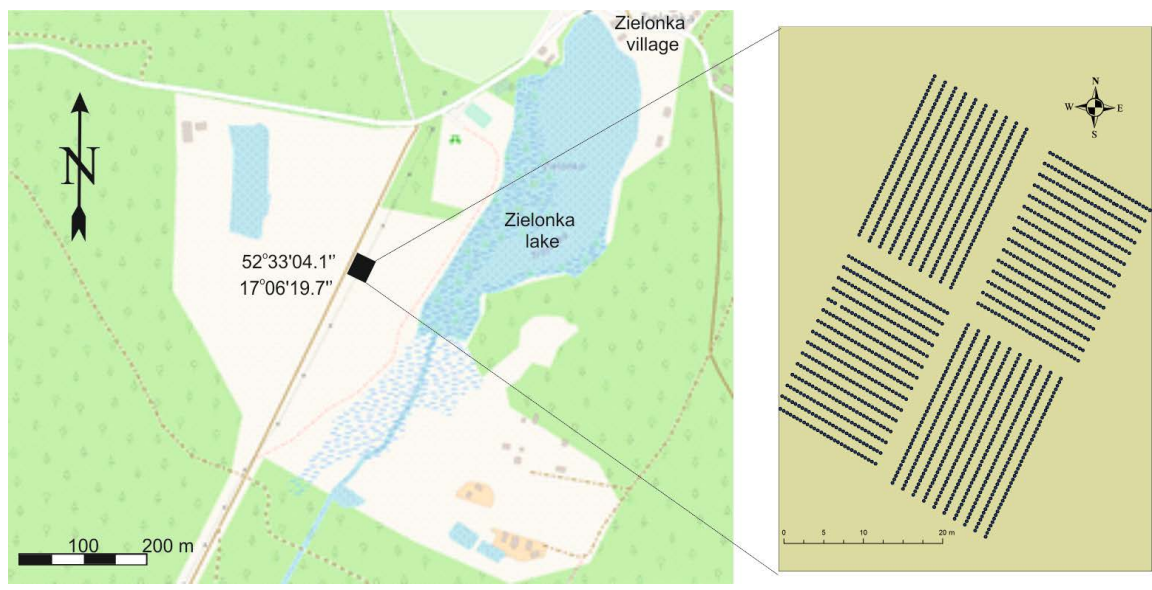

Figure 1. Location of the research area. From the right-side, study design with 4 research plots comprising 150 Salix taxa per plot.

2011, cuttings from 150 willow taxa, collected since 1966 in Poznań University of Life Sciences Willow Collection [14], were planted in the form of four experimental plots (Figure 1). In two plots of $14.5 \mathrm{~m}$ width and $21 \mathrm{~m}$ length, three cuttings of each taxon in a row were planted in the NW-SE direction; in the remaining two plots of $13.5 \mathrm{~m}$ width and $22.0 \mathrm{~m}$ length they were planted in the NE-SW direction (Figure 1). Maintaining the random planting of taxa, the changes in the planting direction, was aimed at ensuring the diversified access of sunlight to the taxa of individual rows. The total research area was $1472 \mathrm{~m}^{2}(32 \times$ $46 \mathrm{~m})$.

\subsection{Methods}

Observations of willow flowering were carried out in the second year of willow growth, as a part of phenological studies, covering the period from March 9 to December 7, 2012, at weekly intervals. Of all 150 taxa, 75 taxa bloomed in the second year since the establishment of the plantation, and included 47 female flowers, 26 male flowers, and 2 showing male and female flowers on one shrub (Table 1). The insects were observed between April 6 and May 11, 2012. The observations were conducted directly by the authors of this study.

The description of flower development took into account the following phases developed and adopted by the authors:

1) The appearance of the first flower buds

2) First flowers bloom

3) The beginning of full flowering (when approximately $25 \%$ of flowers flowered)

4) Appearance of first faded flowers (when the first flowers have withered or shed)

5) End of full flowering (approximately $75 \%$ of flowers stopped flowering)

6) End of flowering (date of the last flowers blooming)

Most of the insects visiting willow flowers were marked directly in the field. In the case of the occurrence of species that could not be identified in the field, 
Table 1. List of studied taxa (F-Female, M-Male, MF-Female and Male flowers on one shrub).

\begin{tabular}{|c|c|c|c|}
\hline No. & Clone number & Names & Sex \\
\hline 1) & $56,196 / 187$ & Salix $\times$ pontederana Schleich. & $\mathrm{F}$ \\
\hline 2) & $\begin{array}{c}10,19,47,93,94,101 \\
102,26 / 18,106 / 93\end{array}$ & Salix $\times$ rubra Huds. & $\mathrm{F}$ \\
\hline 3) & 1 & Salix $\times$ smithiana Willd. & $\mathrm{F}$ \\
\hline 4) & 210 & Salix eriocephala Michx $\times S$. cordata Michx. & $\mathrm{F}$ \\
\hline 5) & $51,202,237,241,253$ & Salix eriocephala Michx. & $\mathrm{F}$ \\
\hline 6) & $307 / 307$ & Salix eriocephala Michx. $\times$ Salix sp. & $\mathrm{F}$ \\
\hline 7) & 204 & Salix eriocephala "Nicholsoni Purpurescens" & $\mathrm{F}$ \\
\hline 8) & $150 / 137$ & Salix eriocephala "Nicholsoni Purpurescens" & $\mathrm{F}$ \\
\hline 9) & 9 & Salix fragilis $\mathrm{L}$. & $\mathrm{F}$ \\
\hline 10$)$ & 52 & Salix myrsinifolia Salisb. & $\mathrm{F}$ \\
\hline 11) & 53 & Salix myrsinifolia "Prunifolia" & $\mathrm{F}$ \\
\hline 12) & $\begin{array}{c}7,21,23,58,63,65,71 \\
75,79,81,82,87,39 / 26 \\
41 / 27,158 / 145 \\
167 / 154,168 / 155\end{array}$ & Salix purpurea L. & $\mathrm{F}$ \\
\hline 13) & 15 & Salix purpurea $\mathrm{L} . \times$ triandra $\mathrm{L} . \times$ viminalis $\mathrm{L}$. & $\mathrm{F}$ \\
\hline 14) & 46 & Salix purpurea L. $\times$ triandra L. $\times$ viminalis $\mathrm{L}$. & $\mathrm{F}$ \\
\hline 15) & 76 & Salix purpurea "Scharfenbergiensis" & $\mathrm{F}$ \\
\hline 16) & $224 / 209$ & Salix sp. & $\mathrm{F}$ \\
\hline 17) & $10-1$ & Salix viminalis $\mathrm{L}$. & $\mathrm{F}$ \\
\hline 18) & $304 / 304$ & Salix viminalis "PR3” & $\mathrm{F}$ \\
\hline 1) & $28,29,30,78 / 64$ & Salix $\times$ rubra Huds. & M \\
\hline 2) & 17 & Salix $\times$ sepulcralis Simonk. & M \\
\hline 3) & 89 & Salix $\times$ smithiana "Semipalatinskiensis" & M \\
\hline 4) & $5,38,221 / 206$ & Salix $\times$ smithiana Willd. & M \\
\hline 5) & 255 & Salix eriocephala Michx. & M \\
\hline 6) & $47 / 33$ & Salix fragilis $\mathrm{L}$. & M \\
\hline 7) & $159 / 146$ & Salix purpurea "Angustifolia" & M \\
\hline 8) & $160 / 147$ & Salix purpurea "Helix Pyramidalis" & M \\
\hline 9) & 68 & Salix purpurea "Angustifolia" & M \\
\hline 10) & $\begin{array}{c}26,67,70,74,78,86 \\
125,19 / 15,151 / 138\end{array}$ & Salix purpurea L. & M \\
\hline 11) & $302 / 302$ & Salix viminalis "PR1" & M \\
\hline
\end{tabular}




\section{Continued}

\begin{tabular}{cccc}
\hline 12$)$ & $303 / 303$ & Salix viminalis “PR2” & $\mathrm{M}$ \\
$13)$ & $305 / 305$ & Salix viminalis “PR4” & $\mathrm{M}$ \\
\hline 1$)$ & 45 & Salix fragilis L. & $\mathrm{MF}$ \\
$2)$ & 83 & Salix purpurea L. & $\mathrm{MF}$ \\
\hline
\end{tabular}

individual specimens were caught using an entomological mesh with a rim diameter of $30 \mathrm{~cm}$, and their species affiliation was determined.

\section{Results}

A total of 1591 individuals belonging to the group of stingers (Apoidea) were noted (Table 2).

The following groups of species were distinguished:

- Bombus "terrestribombus" or a group of bumblebees (Bombus terrestris and three critical species: B. lucorum, B. cryptarum and B. magnus). The latter is rarely recorded in Poland, and it can be ruled out with a high probability. However, it is difficult to assess the proportions of the other three species in the research results. Despite the possibility of isolating $B$. terrestris in the field [15], it was abandoned because of the difficulty of observing fast-moving bumblebees while collecting pollen and nectar.

- Andrena cineraria and $A$. vaga, species were easily distinguishable by the appearance of females, but the vast majority of the counted specimens were males, which are difficult to identify in the field. Nevertheless, based on the size of the females, the proportions of the species were set at 1:9.

- Andrena apicata, A. mitis, and A. praecox. A group of very similar species, cannot be identified in the field. Based on the caught specimens, the proportions in the group were set to 4:1:9.

The analysis of the data contained in Table 2 shows that Colletes cunicularius is dominant, and 938 individuals were counted, constituting $58.7 \%$ of the entire material. It is a species associated with willows, rarely visiting the flowers of other plant species. Its appearance is closely correlated with the beginning of flowering willows. When analyzing the time of appearance, it can be seen that the first counting period had highest abundance (93.6\%) of all specimens of the species (Table 2). Later, its abundance declined sharply, and the appearance of the species essentially ended when the flowers faded. The other dominant species in the groups: Andrena cineraria/vaga, Andrena apicata/mitis/ praecox and Bombus "terrestribombus" behave similarly. In their case, however, it is not related to the biological end of the appearance of the species, but to the flight to other flowering plants, for example, dandelion (Taraxacum) which begins flowering at the end of willow flowering. Other species on willows often appear later, which is related to their different life cycles.

The collected data on the number of insects and the flowering of willows were compared under the weather conditions shown in Figure 2. 
Table 2. List of species with their numbers at particular observation dates. None of the stinger bees were observed in the period before April 14 .

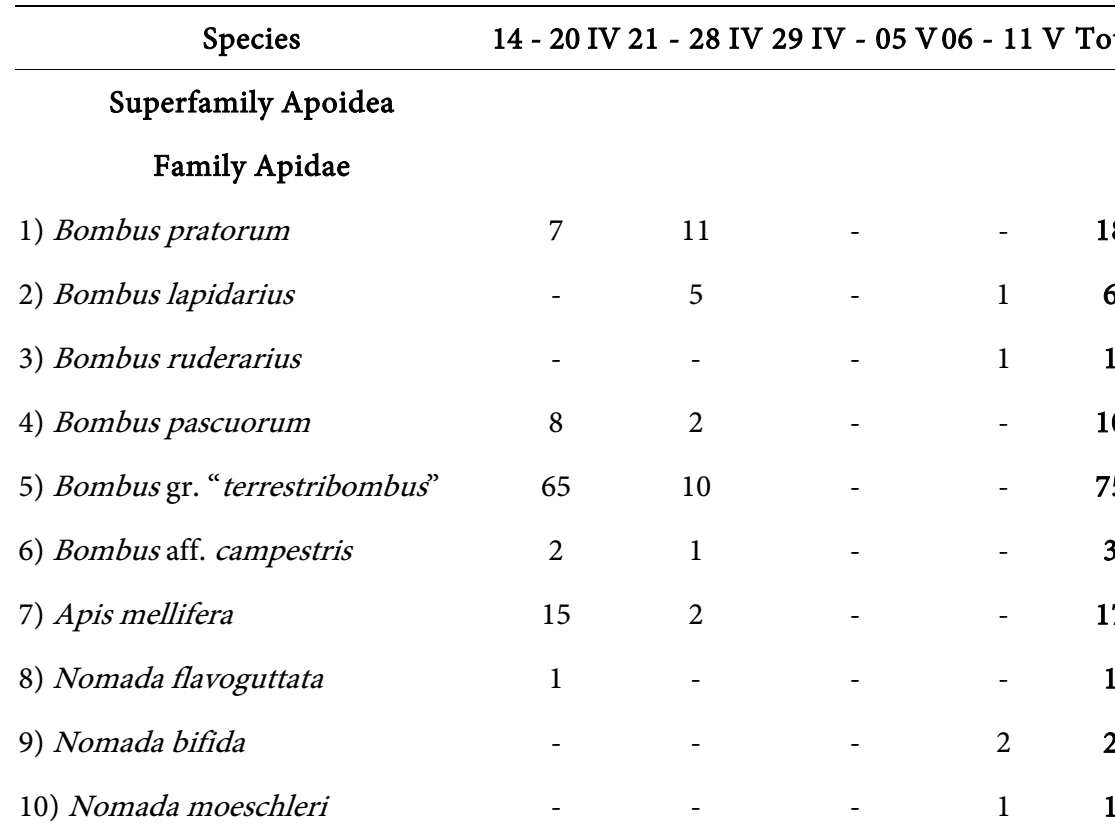

\section{Family Colletidae}

11) Colletes cunicularius

Family Andrenidae

12) Andrena cineraria/vaga

$\begin{array}{ccccc}153 & 114 & 24 & 2 & 293 \\ 11 & 8 & 6 & 2 & 27 \\ 1 & 5 & 3 & 1 & 10 \\ - & 1 & - & - & 1 \\ - & 1 & - & - & 1 \\ 9 & 12 & - & 1 & 22 \\ - & 10 & 4 & 2 & 16 \\ - & 1 & 2 & - & 3 \\ - & - & - & 1 & 1 \\ 1 & 1 & - & - & 2 \\ 67 & 13 & 12 & 2 & 94\end{array}$

22) Andrena apicata/mitis/praecox

Family Halictidae

23) Halictus rubicundus

24) Halictus confusus

25) Lasioglossum xanthopus

26) Lasioglossum subfasciatum

27) Lasioglossum sexnotatum

28) Lasioglossum quadrinotatum

$\begin{array}{lllll}- & 1 & - & - & 1 \\ - & - & 1 & - & 1 \\ 1 & - & - & - & 1 \\ 1 & 2 & - & - & 3 \\ - & - & 1 & 1 & 2 \\ - & 1 & - & - & 1\end{array}$




\section{Continued}

\begin{tabular}{cccccc}
\hline 29) Lasioglossum calceatum & 5 & 24 & 7 & 3 & 39 \\
30) Sphecodes albilabris & - & - & 1 & - & 1 \\
Total & 1225 & 263 & 83 & 20 & 1591 \\
\hline
\end{tabular}

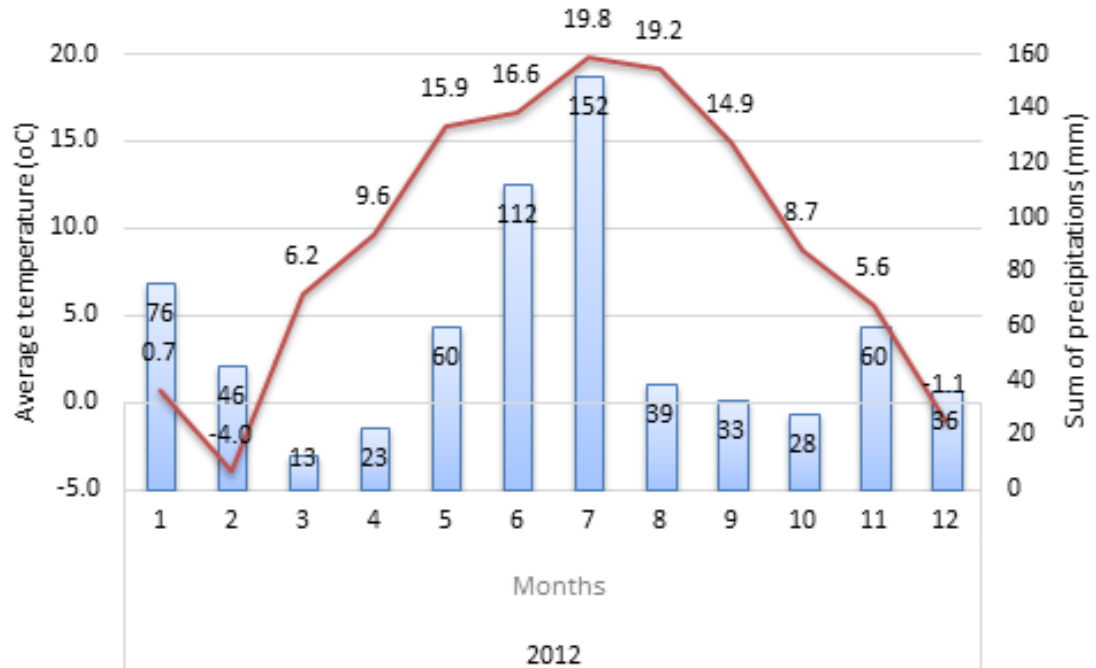

Figure 2. Average monthly values of temperature $\left[\left({ }^{\circ} \mathrm{C}\right)\right.$ red line $]$ and precipitation $[(\mathrm{mm})$ blue bars] in 2012 .

Figure 3 shows the changes in the number of insects in relation to the flowering dates of male and female willows, while in Figure 4, the flowering dates of willows are correlated with weather conditions.

As shown in Figure 3, the greatest number of insects was recorded during the period of the most abundant pollen production. During the period of maximum flowering in female specimens, the number of insects clearly decreasing.

The data presented in Figure 4 show that the willow pollen production optimum occurred when the minimum air temperatures stopped dropping below zero. This parameter and this period are also related to the intensification of occurrence of the noted insects. From Figure 4, it can also be concluded that, the pollen season precedes the flowering optimum of female flowers. It can also be noticed that the optimum flowering of female flowers is correlated with a significant increase in air temperature.

In the described research area of $1472 \mathrm{~m}^{2}$, from April 14 to May 11, 2012, a total of 1591 Apoidea representatives (including only 17 honeybee individuals) were noted, representing 30 species. The culmination of the number of specimens took place from April 14 to 20, during pollen production optimum of willows. After this period, a clear decrease in the number of specimens was observed. After May 11, when pollen production ceased, willow plantation was no longer attractive to the studied pollinators. In the last week of observation (May 5-11), only 20 specimens were recorded. Additionally, differences in the activity of individual species were observed, as shown in Table 3. 
Table 3. Changes in species composition and number of insects at different appearance dates.

\begin{tabular}{|c|c|c|c|c|}
\hline \multirow{2}{*}{ Species } & \multicolumn{4}{|c|}{ Appearance dates and number of insects } \\
\hline & $14-20 \mathrm{IV}$ & $21-28 \mathrm{IV}$ & $29 \mathrm{IV}-05 \mathrm{~V}$ & $06-11 \mathrm{~V}$ \\
\hline Colletes cunicularius & 878 & 38 & 22 & \\
\hline Andrena cineraria/vaga & 153 & 114 & 24 & 2 \\
\hline Andrena apicata/mitis/praecox & 67 & 13 & 12 & 2 \\
\hline Bombus "terrestribombus" & 65 & 10 & & \\
\hline Apis mellifera & 15 & 2 & & \\
\hline Andrena fulva & 11 & 8 & 6 & 2 \\
\hline Andrena haemorrhoa & 9 & 12 & & 1 \\
\hline Bombus pascuorum & 8 & 2 & & \\
\hline Bombus pratorum & 7 & 11 & & \\
\hline Lasioglossum calceatum & 5 & 24 & 7 & 3 \\
\hline Bombus aff. campestris & 2 & 1 & & \\
\hline Nomada flavoguttata & 1 & & & \\
\hline Andrena ventralis & 1 & 5 & 3 & 1 \\
\hline Andrena clarkella & 1 & 1 & & \\
\hline Lasioglossum xanthopus & 1 & & & \\
\hline Lasioglossum subfasciatum & 1 & 2 & & \\
\hline Andrena flavipes & & 10 & 4 & 2 \\
\hline Bombus lapidarius & & 5 & & 1 \\
\hline Andrena dorsata & & 1 & & \\
\hline Andrena minutula & & 1 & & \\
\hline Andrena nigroaenea & & 1 & 2 & \\
\hline Halictus rubicundus & & 1 & & \\
\hline Lasioglossum quadrinotatum & & 1 & & \\
\hline Halictus confusus & & & 1 & \\
\hline Lasioglossum sexnotatum & & & 1 & 1 \\
\hline Sphecodes albilabris & & & 1 & \\
\hline Nomada bifida & & & & 2 \\
\hline Bombus ruderarius & & & & 1 \\
\hline Nomada moeschleri & & & & 1 \\
\hline Andrena nitida & & & & 1 \\
\hline
\end{tabular}




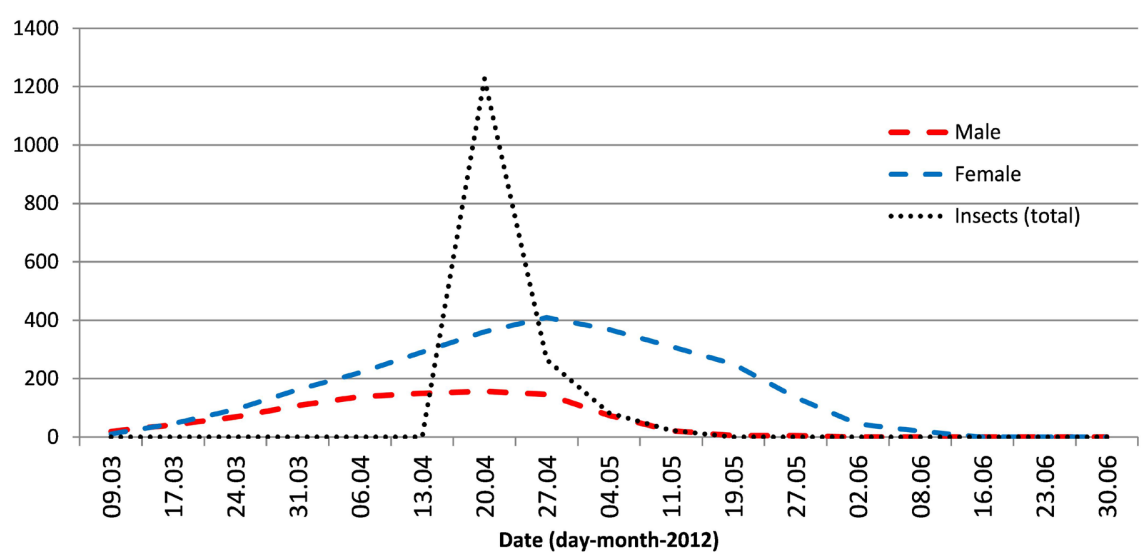

Figure 3. Changes in the number of insects during the flowering of willows.

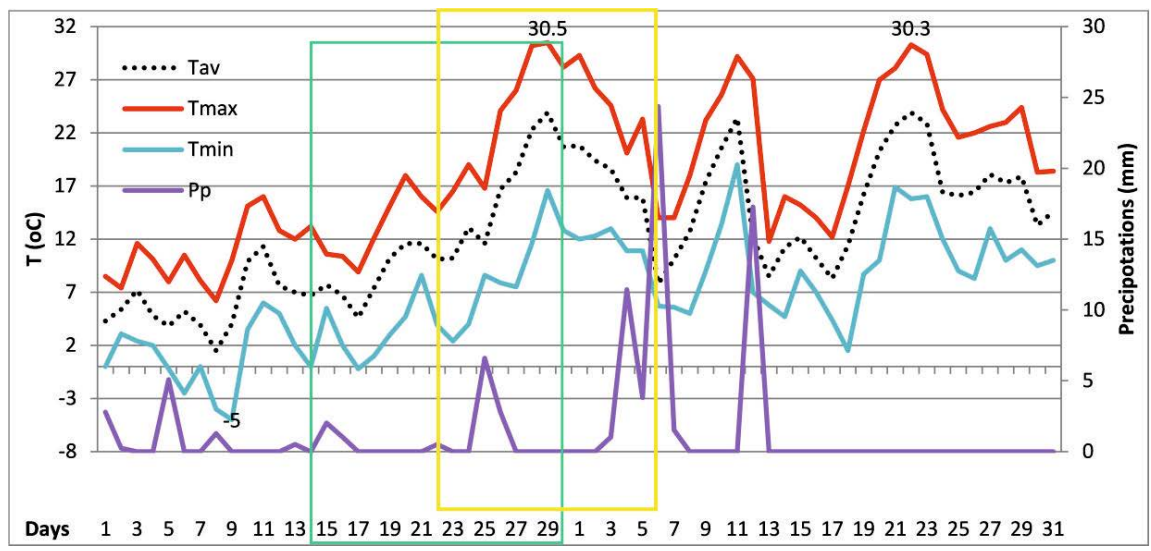

Figure 4. Daily values of temperature and precipitation from April 1 to May 31, 2012. The green rectangle marks the willow pollination optimum, which corresponds to the maximum numbers of insects recorded on the experimental plot. Yellow optimum of flowering of female flowers. Tav, average temperature; Tmax, maximum temperature; Tmin, minimum temperature; $\mathrm{Pp}$, precipitations.

\section{Discussion}

Willow is an extremely valuable first encountered and basic food for pollinators in early spring, allowing them to survive until the period when other nectar and pollen-bearing plants, including crops, bloom. This is important for species with a long period of occurrence, especially for honeybees and bumblebees, which require a continuous food base that determines the number of these valuable insects and the subsequent strength of their families. The research showed the beginning of flowering of male willow flowers from March 9 to May 11, culminating from April 13 to 20, when most pollen-bearing plants in Poland are still in winter dormancy. Female flowers appeared from March 9 to June 8, culminating on April 27. The period of intense pollen production lasted for April. Undoubtedly, it may be subject to natural fluctuations related to weather changes in individual years, which was demonstrated for the eastern part of Poland by, inter alia, Weryszko-Chmielewska et al. [16]. In the cited study, it is also worthwhile to compare the difference in pollen availability depending on the research area, 
which was demonstrated by comparing an urbanized area with the total area of a national park. The study showed higher amounts of willow pollen in the air in urbanized areas. This shows the complexity of the relationships that influences the interpretation of research findings on interactions in the natural world, including interactions between willows and pollinators. Undoubtedly, these relations should take into account not only the places of obtaining food, but also the availability of places where bees find shelter [17]. In relation to plants, both local and global climatic conditions are of significant importance for the interpretation of results. With regard to willows, it is necessary to refer to their sex, which is often omitted in many activities related to the cultivation of willows [2]. Research has shown that the very approach to the roles of native and non-native plant species in the environment, are debatable. The collection of willows on which the research was conducted included 150 taxa, including native and non-native species from the flora of Poland. In the present study, the combined effect of all willows was given, but the study of relationship between individual taxa and specific insect species would undoubtedly require further research. Similarly, it would be advisable to continue the observations so that the obtained results could be interpreted in a more complete way. The relationship between bees and willows of a certain age remains an open question. The study was carried out on willows during the second growing season. In the first one, none of the willows has bloomed yet. In the third year of life (1 year after the research), the willows bloomed more. Therefore, it is difficult to compare the results annually. In particular, the climate of Poland is highly variable. The investigated interactions would therefore require long-term research, taking into account the age of willows, willow species, sex of willows, weather conditions in a given year, environmental features affecting bees, mutual relations between bees, relations between bees and their competitors, and/or the separation of research plots with native and alien species. A possible future appearance of hives close to willow plantations could also be important and could affect other wild species. Repeating the research in the same place but with different components of the experiment (e.g., with a different age of willow trees) may therefore lead to results that are difficult to interpret, for example, in the light of crop planning and calculation of potential yields, which raises the issue of crop profitability. In Poland, approximately 60 species of cultivated plants depend on pollinating insects [18]. The most important are alfalfa, clover, rapeseed, buckwheat, apple tree and other fruit trees and shrubs. Not all bee species fly evenly around these plant species. Honeybees prefer buckwheat and apple trees, bumblebees-clover, and solitary species such as-alfalfa [18], fruit trees and shrubs [19].

Nevertheless, the collected data show the importance of a rich and long-blooming first food base for pollinators, which are willows, including willows of foreign origin. In this context, the creation of targeted plantings of species and varieties with different and at the same time overlapping flowering periods can be of measurable importance in the increased yield of field and fruit crops. This is all the more important when a decrease in the number of pollinators is observed as 
a result of environmental contamination [20], reduction of the nesting area, wastelands with wild flowering plants and other reasons [21].

\section{Conclusions}

The study showed the influence of a small $\left(1472 \mathrm{~m}^{2}\right)$ willow plantation, consisting of 150 taxa of both native and foreign origin, on the presence of 30 Apoidea species. There was also a small proportion of honeybees (17) in relation to the total number of insects observed (1591). This shows that the change in environmental conditions may have an impact not only on the most important representative of Apoidea, but also on other pollinators.

The significant correlation between the number of pollinators and the period of pollen production by willows and the decrease in insect number after the pollination period, despite the peak flowering of female specimens in the studied area, is considered to be a significant result. The observed species of insects were also ranked according to the date of their appearance, distinguishing 4 groups among them. The first to appear were: Andrea mitis, A. praecox, A. vaga, $A$. apicata, A.cineraria, A. clarkella, A. fulva, A. haemorrhoa, $A$. ventralis, Apis mellifera, Bombus "terrestribombus", B. pascuorum, B. pratorum, B. campestris, Colletes cunicularius, Lasioglossum calceatum, L. subfasciatum, L. xanthopus, Nomada campestuttris followed by Andrena dorsata, A. flavipes, A. minutula, $A$. nigroaenea, Bombus lapidarius, Halictus rubicundus, Lasioglossum quadrinotatum.

The last species, with single individuals of a given species, were: Andrena nitida, Bombus ruderarius, Nomada bifida and N. moeschleri.

\section{Conflicts of Interest}

The authors declare no conflicts of interest regarding the publication of this paper.

\section{References}

[1] Ostaff, D.P., Mosseler, A., Johns, R.C., Javorek, S., Klymko, J. and Ascher, J.S. (2015) Willows (Salix spp.) as Pollen and Nectar Sources for Sustaining Fruit and Berry Pollinating Insects. Canadian Journal of Plant Science, 95, 505-516. https://doi.org/10.4141/cjps-2014-339

[2] Konatowska, M., Rutkowski, P., Budka, A., Goliński, P., Szentner, K. and Mleczek, M. (2021) The Interactions between Habitat, Sex, Biomass and Leaf Traits of Diferent Willow (Salix) Genotypes. International Journal of Environmental Research. https://doi.org/10.1007/s41742-021-00323-3

[3] Sacchi, C.F. and Price, P.W. (1988) Pollination of the Arroyo Willow, Salix lasiolepis. Role of Insects and Wind American Journal of Botany, 75, 1387-1393. https://doi.org/10.1002/j.1537-2197.1988.tb14200.x

[4] Kevan, P.G. (1972) Insect Pollination of High Arctic Flowers. Journal of Ecology, 60, 831-847. https://doi.org/10.2307/2258569

[5] Argus, G.W. (1974) Experimental Study of Hybridization and Pollination in Salix (willow). Canadian Journal of Botany, 52, 1613-1619. 
https://doi.org/10.1139/b74-212

[6] Elmqvist, T., Ågren, J. and Tunlid, A. (1988) Sexual Dimorphism and Between-Year Variation in Flowering, Fruit Set and Pollinator Behaviour in a Boreal Willow. Oikos, 53, 58-66. https://doi.org/10.1139/b74-212

[7] Vroege, P.W. and Stelleman, P. (1990) Insect and Wind Pollination in Salix repens L. and Salix caprea L. Israel Journal of Botany, 39, 125-132.

[8] Fox, J.F. (1992) Pollen Limitation of Reproductive Effort in Willows. Oecologia, 90, 283-287. https://doi.org/10.1007/BF00317187

[9] Douglas, D.A. (1997) Pollination, Capsule Damage, and the Production of Seeds in Salix setchelliana (Salicaceae), an Alaskan Glacial River Gravel Bar Willow. Canadian Journal of Botany, 75, 1182-1187. https://doi.org/10.1139/b97-831

[10] Füssel, U. (2007) Floral Scent in Salix L. and the Role of Olfactory Andvisual Cues for Pollinator Attraction of Salix caprea L. Doctoral Dissertation. Universität Bayreuth, Germany.

[11] Danforth, B.N., Minckley, R.L. and Neff, J.L. (2019) The Solitary Bees. Biology, Evolution, Conservation. Princeton University Press, 472.

https://doi.org/10.2307/j.ctvd1c929

[12] Michez, D., Rasmont, P., Terzo, M. and Vereecken, N.J. (2019) Bees of Europe. N.A.P Editions, France, 547.

[13] Nicolson, S.W. and Wright, G.A. (2017) Plant-Pollinator Interactions and Threats to Pollination: Perspectives from the Flower to the Landscape. Functional Ecology, 31, 22-25. https://doi.org/10.1111/1365-2435.12810

[14] Rutkowski, P., Konatowska, M., Goliński, P., Mleczek, M., Szentner, K. and Waliszewska, B. (2015) The Use of GIS Database in the Documentation of Willows of Their Collection at the Poznań University of Life Sciences (Poland). In: Maciej, N., Ed., Scientific, Technological and Legal Background of Creating Integrated Biotic Databases. Adam Mickiewicz University Press. Seria Biologia, 80, 85-90.

[15] Pawlikowski, T. (1999) A Field Guide to Identification of Bumblebees (Hymenoptera: Apidae: Bombini) in Poland. UMK, Toruń.

[16] Weryszko-Chmielewska, E., Piotrowska-Weryszko, K., Sulborska, A., Żuraw, B., Dmitruk, M., Stępniewski, K., Pogorzelec, M. and Voloshchuk, K. (2017) Assessment of Salix spp. Pollen Availability to Insects Based on Aerobiological Investigations. Acta Agrobot, 70. https://doi.org/10.5586/aa.1717

[17] Bennett, A.B. and Isaacs, R. (2014) Landscape Composition Influences Pollinators and pollination Services in Perennial Biofuel Plantings. Agriculture, Ecosystems and Environment, 193, 1-8. https://doi.org/10.1016/j.agee.2014.04.016

[18] Banaszak, J. and Cierzniak, T. (1995) Ekonomiczne efekty zapylania roślin uprawnych przez pszczołę miodną i dziko żyjące pszczołowate (Apoidea). Kosmos, 44, 47-61. https://doi.org/10.1093/ajcn/61.1.44

[19] Wójtowski, F. and Eliszek, H. (1977) Apidofauna zapylająca drzewa i krzewy owocowe w pracowniczych ogródkach działkowych Poznania. Roczniki Akademii Rolniczej w Poznaniu. 94, 235-241.

[20] Banaszak, J. and Izdebska, B. (1994) Wpływ skażeń środowiskowych na pszczoły dziko żyjące, pszczołę miodną i produkty pszczele. Kosmos, 43, 285-302.

[21] Banaszak, J., Czechowska, W., Czechowski, W., Garbarczyk, H., Sawoniewicz, J. and Wiśniowski, B. (2000) Zagrożenia i perspektywy owadów błonkoskrzydłych ( $\mathrm{Hy}$ menoptera) Wiadomości Entomologiczne, 18, 171-211. 